\title{
E-Government for Sustainable Development: Evidence from MENA Countries
}

\author{
lyad Dhaoui ${ }^{1}[$
}

Received: 19 November 2020 / Accepted: 2 April 2021 / Published online: 10 May 2021

(c) The Author(s), under exclusive licence to Springer Science+Business Media, LLC, part of Springer Nature 2021

\begin{abstract}
This research paper investigates the role of electronic government on various aspects of economic and social development in the Middle East and North Africa (MENA) region. The paper uses a panel data of 15 MENA countries between 2003 and 2018. The paper examines, first, the effect of e-government on good governance. Second, it highlights the effect of good governance on sustainable development, and third, it assesses the effect of e-government development on sustainable development, i.e., the digital dividends. The race is between skills and technology, while the outcome will settle on whether the dividends from digital technologies are realized and the benefits widely shared.

The results reveal that most indicators of good governance have a positive contribution to sustainable development. As for the impact of e-government development on governance indicators, findings show that digitalization improves control of corruption and government effectiveness, and to a lesser extent, regulatory quality. Contrary to what was expected, e-government-related variables exert an adverse effect on various aspects of sustainable development instead of being a catalyst for progress. Based on these findings, the paper provides some recommendations. Essentially, policies on the use of digital technologies need to be adequately embedded in public sector reform. MENA countries should promote competitive business environments, enhance accountability, and upgrade education and skills development systems. Our findings are then of great interest to policymakers to make the necessary reforms that reap digital dividends in the form of faster growth, better public services, and adequate environmental management.
\end{abstract}

Keywords E-government · Good governance $\cdot$ Sustainable development $\cdot$ MENA countries

This article is part of the Topical Collection on Digital Transformation and Disruption

Iyad Dhaoui

iyad.dhaoui@gmail.com

Extended author information available on the last page of the article 
JEL classification $\mathrm{H} 11 \cdot \mathrm{H} 41 \cdot \mathrm{O} 10$

\section{Introduction}

Nowadays, good governance has considerable potential for modernizing public administration, improving public service delivery, dealing with increasingly more complex development imperatives, and promoting well-being. It may contribute to the fulfillment of the 2030 Sustainable Development Goals (SDGs) set by the United Nations (Glass \& Newig, 2019). In that regard, information and communication technologies (ICTs) to support governance strategies remains an important driving force for realizing this transition, particularly in the context of international market pressures and global competition. It presents incredible opportunities to innovate, strengthen, and improve the ways of working and creates plenty of advantages. However, the greatest rise of digitalization in history will not truly revolutionary until it benefits everyone in every part of the world (World Development Report: WDR, 2016). In order to seek the economic, social, and environmental needs sustainability, it is necessary to establish both good governance and electronic government (e-government) strategies by identifying the mechanisms, processes, and outcomes (Dhaoui, 2019a).

Digitalization has underpinned every aspect of our daily life. Digital technologies - the internet, mobile phones, and all the other tools to collect, store, analyze, and share information digitally - have spread quickly, and we find ourselves in the midst of the greatest information and communications revolution in human history (WDR, 2016). The COVID-19 pandemic which forces social distancing and quarantine measures lockdowns has renewed and accelerated the role of digital government both in its conventional delivery of digital services as well as new innovative efforts in managing the crisis. Digital solutions have become vital to address isolation and keep people informed and engaged (UN, 2020).

ICTs have influenced how firm operate and how people seek opportunities. Also, they have helped countries to increase growth and improve public service delivery. ${ }^{1}$ More importantly, ICTs have enabled countries to develop e-government initiatives that have changed how citizens interact with their governments, creating an important development in their expectations (Dodd, 2000). To be inclusive, the benefits from using new technologies—digital dividends—should be widely shared among all stakeholders (WDR, 2016).

Over the past decades, developing countries have made efforts to leverage ICTs as drivers of efficiency gains and enhance public sector performance. ${ }^{2}$ While governments intend to achieve the objectives of sustainable development at various

\footnotetext{
${ }^{1}$ The spectacular drop in the price of ICTs has led economic agent (firms and governments) to replace existing factors (labor and non-ICT capital) with ICT capital and to automate some of their activities.

${ }^{2}$ Digital technologies can have impacts on public sector through four channels: informing citizens and giving them an official identity, streamlining processes, receiving feedback, and improving service provider management.
} 
level (economic, social environmental, and so on) through the working system of the economy mainly through the development of institutions, there is further opportunities and contention also that government strategies may result into inefficiency, all depend on the reform success and the advances in accountability (Hauner \& Kyobe, 2010). With the spread of ICTs, capable and accountable institutions are becoming more important. As adopting new technologies raise productivity, the competitive pressure increases. This emphasizes the critical role of a country's business climate. It includes a suitable regulatory framework, i.e., good governance, which can reduce market distortions while building effective competition enforcement. In countries where fundamentals such as regulatory framework, institutions, and skills are weak, it becomes difficult that ICTs can boost productivity or reduce inequality (WDR, 2016). Thus, countries are obliged to reduce the gap between changing technology and unchanging institution.

In the meantime, as technology progresses some skills become obsolete. Workers, entrepreneurs, and public servants must acquire and upgrade new skills that help them become more productive and to seize opportunities in the digital world, i.e., adapting their skills to the demands of the new economy (WDR, 2016).

Despite all these debates, the arguments of whether the electronic government and good governance contribute positively to various aspects of sustainable development have become an accepted premise in most economies world over. To achieve broader policy objectives, developing countries have made efforts to leverage ICTs over the past decade and Middle East and North Africa (MENA) countries do not escape this pattern. However, digital government efforts in the region are still perceived as technical support activities and not as a core strategic component of public sector activities (OECD, 2017). The alternative would be that e-government should be value-driven instead of technology-driven.

This paper analyses whether electronic government is a catalyst for boosting the impact of good governance and more importantly its impact on sustainable development in MENA countries. The paper also examines the impact of good government on the sustainable development. Thus, this paper attempts to answer the following three research questions:

1. What are the impacts of electronic government on good governance in MENA countries?

2. What are the impacts of good governance, i.e., good institutions, on the sustainable development in the region?

3. Does electronic government improvements accelerate the impacts on various aspects of sustainable development of MENA countries, i.e., whether the dividends from digital technologies are realized and the benefits are widely shared?

The primary concern of the present paper is to obtain empirical evidence and to increase the level of awareness in relation to electronic government and good governance and their contribution to sustainable development in a sample of 15 MENA countries over the period span 2003-2018. The specific objectives are threefold: first to assess the effect of e-government on good governance and sustainable development in MENA countries; second to identify key success factors which make the difference in e-government development among MENA countries, and third to suggest 
relevant policy recommendations on e-government for sustainable development in MENA countries.

The paper utilizes comparative analysis and advanced econometric measures such as ordinary least square, fixed effects, and random effects models to answer the three questions and accomplish its objectives. The empirical results from this investigation may be useful as fellows. First, they offer an assessment for electronic government and good governance and their impacts on economic, social, and environmental development. Second, empirical findings bring attention with regard to the importance of ICT improvements towards accelerating the impacts of good governance on sustainable development.

Following the introductory motive, the remainder of this paper is set out as follows. "Insight from Literature Review" section discusses the literature review focusing on electronic governance, good governance efficiency, and sustainable development relationships. Data and methodology which are used by this paper to answer the three stated research questions and fulfill the intended objectives are presented in "Data and Methodology" section. While "Empirical Results" section deals with empirical results; "Conclusion and Policy Recommendations" section offers conclusion and policy implications.

\section{Insight from Literature Review}

A good understanding of the relationships between e-government, good governance, and sustainable development requires first knowledge and definition of these relevant concepts. As for e-government, it involves the use of ICTs to transform the workings of government organizations and their relationship with citizens, businesses, and other arms of governments. It is introduced as a means to reduce costs, improve services for citizens, and increase the effectiveness and efficiency of the public sector (Signore et al., 2005). According to Gordon (2002), e-government is the use of ICTs (blockchain, robotics, Internet of Things, artificial intelligence, Big Data, etc.) to improve the process of government. In a narrow sense, it is sometimes defined as citizen's services, re-engineering with technology, or procurement over the Internet (Signore et al., 2005). For Spremić et al. (2009), e-government is the use of information technologies and the Internet for better delivery of government services to citizens.

As for sustainable development, this concept has become a topic of discussion at the international level for many decades. Sustainable development is the "development that meets the needs of the present without compromising the ability of future generations to meet their own needs" (UNWECED, 1987). The objectives of sustainable development include, among other, stable and long-term economic growth, social development (education, health, etc.), preservation of the environment, etc. Current development challenges are more complex. Indeed, and according to the SDG agenda, sustainable development should concern economic, social, and environmental dimensions (Dhaoui, 2019a; UNDP, 2014). 
E-government for sustainable development (EGOV4SD) is the use of ICT to support public service, public administration, and the interaction between government and the public while enabling public participation in government decision-making, promoting social equity and socioeconomic development, and protecting natural resources for future generations (Estevez \& Janowski, 2013).

As for good governance, it refers to the management of government in a manner that is essentially free of abuse and corruption, with due regard for the rule of law and respect of people's rights to be engaged in public affairs. Mira and Hammadache (2017) define good governance as the quality management and orientation of development policies is assumed by many economists, having a positive influence on economic performance. Good governance can be also defined as "a set of qualitative characteristics relating to processes of rulemaking and their institutional foundations. It encapsulates values such as enhanced participation, transparency, accountability, and public access to information. Also, it also helps to combat corruption and secures both basic human rights and the rule of law" (UNU-IAS, 2015).

The following discussions present some past studies which examine the relationships between e-government, good governance, and sustainable development. It should be noted that most of these studies overlooked the connotation of modeling nexus effects between the three dimensions while analyzing impact relationships, thus attracting partial analysis.

As regards the effect of e-government on good governance, e-government is perceived by international development agencies as a key policy priority and a crucial element of the good governance agenda (Madon, 2009). Indeed, UNESCO (2005) points out that with a performing electronic government, both the process of disseminating the information to the public and other agencies and the administrative activities will be efficient, speedy, and transparent. In other words, the e-government may increase government accountability. Kettani and Moulin (2014) argue that e-government makes the government more efficient, responsive, transparent, and legitimate. Thus, e-government is not just a bridge between various agents. It embodies new concepts of citizenship, both in terms of citizen's needs and responsibilities. ICTs have many features such as high-quality and cost-effective government operations, public service improvements, citizen engagement, and more successful administrative and intuitional reforms. The linkage between e-government and corruption at the country/state level has been addressed by relatively few papers (e.g., Mahmood, 2004; Andersen \& Rand; 2005; Pathak et al., 2007). Ojha et al. (2008) point out that, from the available studies, it appears that if e-government readiness index (or proxies of citizen' access to ICT) is taken as the independent variable, then e-government would appear to exert a negative effect on corruption. However, if a variable or index reflecting e-government development/maturity is chosen as the independent variable, then it appears that e-government may have very little or no influence on corruption.

As regards the effect of good governance on sustainable development, the SDG framework emphasizes the key role of effective, accountable institutions for all and 
Goal 16 is dedicated to it. ${ }^{3}$ Important aspects of institutional development are largely rooted in the targets of several of the other 16 goals. Since the past decades, many countries have modernized their institutions and decision-making process in order to make the transition to the market economy, especially by the end of the Cold War (Hout, 2007). The increase in the level of external debt pushed many developing countries launched structural adjustment and upgrading programs, including their governance systems. The accelerated globalization and the unregulated market is also another reason for the emergence of good governance framework (Craig \& Porter, 2006). Large bodies of studies have examined the nexus between good governance and sustainable development. Empirical results differ according to the countries or region and according to the econometric methods. Some studies show a nonconclusive link. Other studies demonstrate a negative link. However, the majority of empirical works prove a positive and direct effect of good governance to achieve sustainable development objectives such as reducing poverty, improvement of health outcomes, more equitable redistribution of income, environment sustainability, institution accountability, and so on (Shylendra \& Bhirdikar, 2005; Kioe Sheng, 2010). According to Juknevciene and Krateivaite (2012), accountable institutions can help citizens to achieve sustainability by providing equal opportunities and contribute heavily to the maintenance of human rights, environmental protection, stable macroeconomic conditions, health conditions improvement, and a good management and mobilization of resource for essential public services. West et al. (2009) contribute to the establishment of an appropriate public policy.

As regards the effect of e-government on sustainable development, the aim of e-government is mainly to provide better services to citizens in an efficient way and thus to facilitate the achievement of sustainability at various levels. Thus, the strategies of e-government development should be value-driven instead of technologydriven since benefits from e-government do not take place by digitizing and placing it online. Marthandan and Tang (2010) spread out the concept of e-government by focusing on the features of interactions between economic, political, and social actors. Indeed, e-government allows the government, citizens, businesses, and customers to work more efficiently. The linkages between government and citizens (B2C), government and businesses (G2B), businesses with each other (B2B), and businesses and customers (B2C) would be easier and with low cost (Dhaoui, 2019b) and service elapsed time decrease. Lim (2014) examines the effects of e-government on good governance and on sustainable development for a sample of 22 countries in SIDS using comparative analysis and econometric modeling. He found a positive and significant impact of e-government on good governance. Concerning the impact of good governance on sustainable development, he also found a significant link.

Although significant efforts have been dedicated to e-government and sustainable development individually, research at the intersection of these domains is scarce (Esteve et al., 2013). Thus, systematic e-government for a sustainable development research framework is yet to emerge.

\footnotetext{
${ }^{3}$ Goal 16 aims to "promote peaceful and inclusive societies for sustainable development, provide access to justice for all and build effective, accountable and inclusive institutions at levels."
} 
Table 1 EGOV4SD conceptual framework

EGOV

Government

Technology Interaction Customer Society

Solution space

\author{
SD Social Problem space Contribution space \\ Environmental \\ Economic \\ Institutional
}

Esteve et al. (2013), the Proceedings of the 14th Annual Conference on Digital Government Research, p.93

Esteve et al. (2013) present an empirical analysis of 10 case studies of e-government for sustainable development including context, problems addressed, and solutions applied. The most common sustainable development problems addressed are empowerment (social), business opportunities (economic), man-made activity (environmental), and capacity-building (institutional). Their findings reveal that EGOV4SD intuitive contributes to a variety of SD goals with a clear difference between countries. In developed countries such as Singapore and Hong Kong, the efforts are in re-provisioning the second-generation ICT government infrastructure relying upon cloud services and green IT technologies to enable ecosystem-based service delivery. In the case studies for developing countries such as India and Rwanda, the efforts aimed at delivering concrete services to rural populations. To clearly show the conceptual framework of EGOV4SD, Esteve et al. (2013) define a matrix between four dimensions of its problem domain and five dimension of its solution domain. The cell of the matrix characterize the contribution space, matching problems, and solutions across dimensions (Table 1).

Esteve et al. (2013) point out that the relations are asymmetric in the sense that one domain (solution domain) helps fulfill the goals of another domain (problem domain). It is worth noticing that SD is a problem at any relation. As for ICT, it is always a solution domain while GOV is a problem in relation to ICT and a service domain in relation to $\mathrm{SD}$. When taking into account EGO4SD, SD is the problem domain and EGOV is the solution domain.

Some studies show that many e-government projects implemented in some countries have not resulted in significant improvements in citizen services and welfare (Benjamin, 2001; Gartner Group, 2002; Heeks, 2003, 2006; Kanungo, 2003; UNDESA, 2003). Madon (2009) argues that the low usage of e-government leads to a lack of equity in providing access to e-government applications.

According to the World Development Report (WDR, 2016), many digital projects fail. The WDR points out that only $35 \%$ of the roughly 530 ICT projects in developing countries from 1995 to 2015 were evaluated satisfactory or above. The WDR explains that in some cases, even if e-government projects are successfully implemented, they may actually worsen outcomes as "without proper regulatory safeguards in place" (WDR, 2016 p. 165). 
A number of reports and studies have revealed that most countries in the MENA region and many parts of their societies are not well outfitted and equipped to utilize new ICTs for further development (i.e. UNDP 2016, ESCWA 2015, WEF 2017, Baller et al., 2016).

\section{Data and Methodology}

This section of the paper discusses data and the methodology which is applied by this paper to analyze the impacts of e-government and good governance on the sustainable development of 15 selected countries of the MENA region.

\section{Data and Variable Description}

This paper uses panel data of the following MENA countries: Algeria, Bahrain, Egypt, Iran, Iraq, Jordan, Kuwait, Lebanon, Morocco, Oman, Qatar, Saudi Arabia, Tunisia, Turkey, and United Arab Emirates. The time span covers the period from 2003 to 2018. Libya, Syria, and Yemen are not incorporated in this analysis because of their war-stricken nature. Therefore, this analysis covers the 15 countries in the MENA region. This paper uses panel data because they have more variability and allow to explore more issues than do the cross-sectional or timeseries data alone (Kennedy, 2008). They give more informative data, more variability, less colinearity among the variables, more degrees of freedom and more efficiency, as argued by Baltagi (2001) and capable to surmount the problem of endogeneity (Baltagi, 2001; Hsiao, 2003). The time span 2003-2018 is preferred because data for e-government are obtained sequentially from 2003.

As we mentioned, the paper seeks to explore the impacts of relationships between three main variables: e-government, good government, and sustainable development. The e-government is highlighted through four key variables which are ICT infrastructure (TII), ability to use e-government (HII), e-service infrastructure (OSI), and e-participation index (EPI). The UN e-governance survey on "e-government in support of sustainable development" offers a snapshot of trends in the development of e-government in many countries. The e-governance readiness index (EDGI) is calculated as below:

EDGI $=1 / 3$ (OSI normalized + TII normalized + HCI normalized).

Data for these variables are available for the years 2003, 2004, 2005, 2008, $2010,2012,2014,2016$, and 2018. Due to the importance of these variables in our analysis and also because these variables have a linear trend (either increasing or decreasing), we replace missing data by linear interpolation method. According to the UN e-governance survey, TII is based on data provided by the International Telecommunications Union (ITU). HCI is based on data mainly provided by the United Nations Educational, Scientific and Cultural Organization (UNESCO), and OSI is based on data collected from an independent Online Service Questionnaire (OSQ), conducted by UNDESA, which assesses the national online presence of all United Nations Member States, complemented by a Member State Questionnaire (MSQ). 
Good governance is highlighted through three variables: government transparency and government effectiveness (Goveff), control of corruption (CoC), and regulatory quality (RQ). Sustainable development encompasses four dimensions: economic development, social development, environmental management, and disaster management. Data for these variables come from the World Bank worldwide governance indicators (WGIs).

The GDP per capita, constant 2010, USD (GDPC) is used as a measurement of economic development. The social development is examined through three variables which are political stability and absence of violence (PS\&AV), health index (HI), and under five mortality rate (UFM).

Life expectancy at birth expressed as an index using a minimum value of 20 years and a maximum value of 85 years. The indicator score for each unit is standardized as below:

$I^{S}=\frac{I-\min (I)}{\max (I)-\min (I)}$, where $I$ is the value of life expectancy at birth for a unit, $\max (I)$ is a maximum value of $I$ over a unit, $\min (I)$ is the minimum value of $I$ over a unit minus a small value. Data for GDPC, PS and AV, UFM, and HI come from the World Bank data portal (WDI).

Other dimensions of sustainable development include ecosystem vitality (EV) to measure environment management and vulnerability (VUL) to natural disasters as a measurement of natural disaster management. The data source for the EV variable is the Environmental Performance Index Report led by the Yale Center for Environmental Law and Policy (YCELP) and other organizations. The data source for the VUL variable is the World Risk report (Alliance Development Works and UNU-EHS).

We use also four control variables covering four areas such as democracy, social condition, interaction variable, and measurement method. For democracy, we use voice and accountability (VA) to show the extent to which a country's citizens are able to participate in selecting their government and also to measure freedom of expression, association, and a free media. Data for this variable come from the WDI dataset. For social conditions, we use the size of the population (POP). Also, the interaction between VA and the environmental performance index (EPI) is also employed as an interaction variable. Finally, it is worth noticing that the UN e-government survey for 2014 changed the components of the human capital index (HCI) by adding expected years of education and means years of schooling to the index. For this reason, we add a measurement method related control variable which is a dummy variable (HCIND) that takes the value zero for the observation 2003-2013 and the value one for the 2014-2018 time span.

More detailed about variables and their components or sub-components used in this research paper are detailed in Appendix 1.

\section{Empirical Model Specification}

To the best of our knowledge, there are few papers in MENA countries which examine electronic governance while analyzing the impacts of good governance on 
various aspect of sustainable development. In addition, sustainable development is highlighted through many dimensions such as GDP per capita, health indicators, and environmental and disaster management.

To examine the various impacts in relationship, the paper uses econometric modeling and comparative analysis methods. The approaches implemented here are inspired by the study of Lim (2014) of SIDS countries. The econometric approach is based on three main models. Model (a) tries to examine the effect of e-government on good governance. Model (b) examines the effects of good governance on sustainable development, while model (c) looks at the effect of e-government on sustainable development. Our research design can be summarized in the below graph (Fig. 1).

The general expression of a panel data model is as below:

$$
y_{i t}=\alpha_{i t}+\beta X_{i t}+\varepsilon_{i t}, \quad i=1, \ldots, n, t=1, \ldots, T
$$

The pooled model is

$$
y_{i t}=\propto+\beta X_{i t}+\varepsilon_{i t}, E(\varepsilon \mid X)=0
$$

The estimation method for pooled model is the ordinary least square (OLS) method.

Now, we assume heterogeneity

$$
E\left(\varepsilon_{i t} \mid \propto_{i}, x_{i 1}, \ldots, x_{i T}\right)=0, \quad t=1, \ldots, T
$$

For the random effect (RE) model, $\propto_{i}$ (individual effect) is random variable and uncorrelated with $x_{i t}$ :

$$
y_{i t}=\alpha_{i}+\beta X_{i t}+\varepsilon_{i t}
$$

The pooled OLS works well for RE models.

For the fixed effect model (FE), $\alpha_{i}$ is random variable and correlated with $x_{i t}$ :

$$
y_{i t}=\alpha_{i}+\beta X_{i t}+\varepsilon_{i t}
$$

The pooled OLS is inconsistent for FE and does not work well for works well for RE models.

The guideline of model selection is based on F test, M test, and Hausman test (Park, 2011; Wooldrige, 2013). The results of these tests are reported in Appendix 3.

We use the F test (Fisher test) to compare the FE model and the pooled OLS model. F test gives an indication of goodness of fit. The null hypothesis is that all dummy parameters except for one for the dropped are a zero $\left(\mu_{1}=\cdots=\mu_{n-1}=0\right)$. If the null hypothesis is rejected (an increase of goodness of fit), FE mode is better than pooled OLS.

We use LM test (Lagrange multiplier test) to contrast the RE model to the pooled OLS model. The null hypothesis is that individual (or time) specific variance is zero $\left(\delta^{2}=0\right)$. If the null hypothesis is rejected, RE mode is able to deal with heterogeneity better than the pooled OLS.

The Hausman test is employed to test the similarity between FE and RE models. The null hypothesis is that individual effects are uncorrelated with any regressor in 
the model. We conducted a Hausman test when both hypotheses of the F test and LM test are all rejected. If the null hypothesis of non-correlation between an individual effect and regressors is rejected, we choose the FE model; otherwise, the RE model would be preferred.

After the econometric modeling, we will conduct a comparative analysis. We focus on 2018 as a benchmarking year. First, we analyze a scatter plot of the EDGI and GDP per capita to show whether the correlation between the two variables is positive or negative, has a linear or exponential tendency. Second, based on the mentioned scatter, we divide the sample countries into groups, and for each group, we put its performance in good governance (CoC, Goveff, and RQ) and in sustainable development (GDPC, RoL, PS\&AVT, UFM; HI, HI, EV, and VUL). For each variable, we calculate the average. For each country, we count the number of good performances. We assume that "good performance" acquire when a country's index in a variable is equal or exceed the average and it is not negative. Third, we plot a scatter of EDGI and a number of good performances in good governance and sustainable development to show the sign and tendency of the relationship and to check whether the country grouping still the same. Finally, we will try to study what makes the difference between the groups.

As for the expected results and policy implications, first, for the effect of e-government on good governance, we expect that e-government development has a significant impact on the majority of good governance indicators. Second, for the effect of good governance on sustainable development, we expect that good governance will have a positive and significant effect on the majority of the sustainable development dimensions. Third, for the effect of e-government development on sustainable development, we expect that the improvement of e-government will significantly affect various indicators of sustainable development.

In accordance with the expected data analysis and the possible outcome of the theory and the questions raised, the major expected result is to translate the research's objectives to particular knowledge, commitment, and actions. Indeed, the paper is to be considered as a feasibility study to better understand special challenges and opportunities of digital governance for various aspects of sustainable development and resilient societies in MENA region. An additional result is to generate valuable outputs to ascertain and recognize governance-based digital as one of the most underpinnings of good governance mechanism.

\section{Empirical Results}

In the MENA region, the level of achievement of SDGs, governance system performance, and the investment in advanced technologies and solutions are different from one county to another, including sometimes within the same state.

The global economic crisis of 2008 and the impacts of the Arab spring hit the economies hard, and the countries of the region are struggling to regain their pre-revolutionary growth level. They have faced many challenges in terms of creating decent jobs, building constructive social dialogue, and improving social justice (Dhaoui, 2020). The uprisings that erupted in 2010 and 2011 in half a dozen 
countries in the region have brought to light key challenges that had already existed for some time such as low job creation, pervasive corruption, and lack of accountability and transparency (O'Sullivan et al., 2012). The uprisings and their truncated aftermath raise many important questions about political reforms, especially in terms of institutional structures. Individuals are seeking to become active citizens. Recently, The COVID-19 pandemic has exposed serious vulnerabilities in MENA societies, institutions, and economics. The consequences of the pandemic are likely to be deep and long-lasting, and the region's economy is expected to contract by $5.7 \%$ (UN, 2020).

As regards the economic performance, the MENA region witnessed lower annual growth rates in output, compared to many other developing regions in the world (World Bank, 2014). Some countries in the MENA region have made remarkable progress in many development goals, especially in the area of education and health. However, there are certain aspects of human development in which MENA countries have not progressed as far such high level of unemployment, widespread inequality, environmental degradation, etc. (Dhaoui, 2019c).

The human development index (HDI) for the MENA region was 0.699 in 2018, compared to 0.771 for Europe and Central Asia and to 0.535 for sub-Saharan Africa. In general, MENA countries are ranked among countries with intermediate levels of development. The index is lower than its global counterpart at the world level which was 0.728 in 2018 . Taking into account the inequality factor in the HDI calculation, the MENA countries in general recorded a decline in their results of about $25 \%$.

As regard to e-government, the MENA countries are characterized by large public sectors and a complex regulatory structure and regulations. The implementation of ICTs to modernize public institutions has emerged and is growing. However, dividends seem to be limited. Also, digital and data skills are still scarce and unevenly disrupted across territories. The budgetary constraint is another challenge for the implementation of digital government strategies (OECD, 2017). The difference in levels of digital development in the MENA region is significant (e.g., Thunert, 2009, UNDP, 2012, ESCWA, 2015, Chambers, 2015). Indeed, the region encompasses a wide variety of trajectories within the economy (i.e., general preconditions, differences between oil-exporting countries and oil-importing countries, outsourcing, startup cultures, etc.). Factors such as the distribution of basic infrastructure, enabling business culture, and supportive economic and education policies are very different between as well as within most countries (Göll \& Zwiers, 2018).

The trends in the MENA region are very diverse due to different levels of development both between and within countries. However, adequate governance for innovation and specifically ICT is severely lacking in most of the MENA countries (Göll \& Zwiers, 2018). According to the International Telecommunications Union (ITU), internet use ranges from 30 to $80 \%$ across MENA and there is a gender gap in favor of men in many countries. The gap is also between rural and urban areas in almost all countries of the region. "High-speed internet penetration is low in MENA compared to emerging regions in Europe and Asia. With the exception of Gulf countries, where internet access is available to broad segments of the 
Table 2 Descriptive statistics of variables (2018)

\begin{tabular}{|c|c|c|c|c|c|c|}
\hline & Variable & Mean & Std. dev & Coef of var & Min & Max \\
\hline \multirow[t]{5}{*}{ Measures on e-governance development } & EDGI & 0.620 & 0.141 & $22.7 \%$ & 0.337 & 0.829 \\
\hline & OSI & 0.663 & 0.214 & $32.3 \%$ & 0.215 & 0.944 \\
\hline & TII & 0.514 & 0.192 & $37.4 \%$ & 0.184 & 0.856 \\
\hline & $\mathrm{HCI}$ & 0.684 & 0.089 & $13.0 \%$ & 0.509 & 0.814 \\
\hline & EPI & 0.643 & 0.211 & $32.8 \%$ & 0.202 & 0.943 \\
\hline \multirow[t]{6}{*}{ Measures on good governance } & $\mathrm{CoC}$ & -0.206 & 0.683 & $331.6 \%$ & -1.399 & 1.151 \\
\hline & Goveff & -0.063 & 0.627 & $995.2 \%$ & -1.320 & 1.431 \\
\hline & PS\&AV & -0.638 & 0.928 & $145.5 \%$ & -2.555 & 0.743 \\
\hline & RQ & -0.232 & 0.680 & $293.1 \%$ & -1.296 & 0.931 \\
\hline & RoL & -0.121 & 0.682 & $563.6 \%$ & -1.759 & 0.806 \\
\hline & VA & -0.935 & 0.452 & $48.3 \%$ & -1.644 & 0.210 \\
\hline \multirow{7}{*}{$\begin{array}{l}\text { Measures on economic and social devel- } \\
\text { opment }\end{array}$} & LGDPC & 9.236 & 1.007 & $10.9 \%$ & 7.974 & 11.054 \\
\hline & HI & 0.863 & 0.038 & $4.4 \%$ & 0.776 & 0.924 \\
\hline & UFM & 13.820 & 6.941 & $50.2 \%$ & 6.800 & 26.700 \\
\hline & CEPI & 0.583 & 0.059 & $10.1 \%$ & 0.432 & 0.678 \\
\hline & EV & 0.482 & 0.090 & $18.7 \%$ & 0.310 & 0.635 \\
\hline & VUL & 41.872 & 6.451 & $15.4 \%$ & 31.510 & 56.550 \\
\hline & 1POP & 16.568 & 1.325 & $8.0 \%$ & 14.266 & 18.404 \\
\hline
\end{tabular}

Source: sorted by the author

population, in many countries of the Arab world fewer than a quarter of households have access to this essential tool. Millions of people cannot afford internet services and are therefore excluded from the information revolution that is shaping the modern world" (Gelvanovska et al., 2014).

Concerning governance system performance, there is a substantial cross-country variance in the related indicators, as well as variance in the responses to each of the indicators for individual countries.

The issue now is how e-government initiatives can help MENA countries achieve better results in their governance and therefore their development policy goals. To go deeper into the analysis, we present a brief stylized fact with reference to our sample countries.

Table 2 presents a short description of data expected to estimate results in both econometric and comparatives analysis. The benchmarking year here is 2018 .

The coefficient of variation of good governance variables is higher when considering the good governance measures than the e-governance measures and to a lesser extent the variables of economic and social development, except the under-five mortality rate variable. A higher value of the coefficient of variation means a greater the dispersion around the mean, especially for government effectiveness, rule of law, and control of corruption.

On average, the EDGI in 2018 is 0.620 for the sample countries, compared to 0.773 for Europe and to 0.578 for Asia. The EDGI score was 0.384 in 2003 and 0.465 in 2010 for the sample countries in our analysis. The lowest value is 
Table 3 Effects of e-government development on good governance

\begin{tabular}{llll}
\hline & $\begin{array}{l}\text { Control of corruption } \\
\text { (Eq.a.1) } \\
\text { Pooled OLS }\end{array}$ & $\begin{array}{l}\text { Government effectiveness } \\
\text { (Eq.a.2) } \\
\text { Pooled OLS }\end{array}$ & $\begin{array}{l}\text { Regulatory quality } \\
\text { (Eq.a.3) } \\
\text { Pooled OLS }\end{array}$ \\
\hline OSI & $1.508^{*}$ & $1.145^{*}$ & $1.728^{*}$ \\
& $(0.376)$ & $(0.325)$ & $(0.325)$ \\
TII & $1.304^{*}$ & $1.396^{*}$ & 0.438 \\
& $(0.367)$ & $(0.317)$ & $(0.317)$ \\
HCI & -0.128 & 0.145 & -0.059 \\
& $(0.386)$ & $(0.333)$ & $(0.333)$ \\
EPI & $-1.050^{*}$ & $-0.726^{* *}$ & $-0.536^{* * *}$ \\
& $(0.353)$ & $(0.305)$ & $(0.305)$ \\
VA & 0.104 & $0.417^{* *}$ & $0.400^{* *}$ \\
INTER & $(0.202)$ & $(0.174)$ & $(0.174)$ \\
POP $(\log )$ & -0.047 & $-0.521^{* * *}$ & -0.318 \\
& $(0.343)$ & $(0.296)$ & $(0.296)$ \\
HCIND(1) & $-0.167^{*}$ & $-0.116^{*}$ & $-0.238^{*}$ \\
& $(0.029)$ & $(0.025)$ & $(0.025)$ \\
Constant & $-0.264^{* *}$ & $-0.308^{*}$ & $-0.335^{*}$ \\
$N$ & $(0.116)$ & $(0.100)$ & $(0.100)$ \\
$R^{2}$ & $2.114^{*}$ & $1.278^{* *}$ & $3.382^{*}$ \\
Prob $(F)$ & $(0.619)$ & $(0.535)$ & $(.534)$ \\
\hline & 240 & 240 & 240 \\
& 0.495 & 0.544 & 0.640 \\
& 0.000 & 0.000 & 0.000 \\
\hline
\end{tabular}

Values between parentheses are the standard errors

* $1 \%$, ** $5 \%, * * * 10 \%$

registered in Iraq (0.337), while the highest value (0.830) is in the United Arab Emirates (UAE). The e-participation index (EPI) is 0.643 in 2018, compared to 0.086 in 2003 and 0.202 in 2010 . The average score of control of corruption for MENA countries is -0.206 . The lowest score is registered in Iraq $(-1.399)$, while the highest value is in UAE (1.152). The worst performance of the region, on average, is registered for the variables voice and accountability, and political stability and absence of violence. The health index remains in acceptable range $(0.863)$, while the under-five mortality rate and the environmental variables seem to be under the hoped for. Overall, disparities between countries appear. More detailed statistics are in Appendix 2. Now, we present the estimation results based on the approaches mentioned above in order to answer the three research questions.

Results in Table 3 present the estimation of the effects of e-government development on good governance. We use control of corruption (Eq.a.1), government effectiveness (Eq.a.2), and regulatory quality (Eq.a.3), as endogenous variables. According to the selection process of modeling, based on F test and LM test, pooled OLS method is more suitable for our mode than the EF or RE models. 
The results demonstrate the following. Online service development and ICT development contribute positively and significantly to control of corruption. When considering government effectiveness, OSI and TII have also a positive impact. For the regulatory quality equation, OSI has a positive significant contribution while TII and HCI exert non-significant impacts. The human component has a positive impact on government effectiveness, but this impact is insignificant. We can say that e-government development works well for the control of corruption and government effectiveness, and in a lesser extent, for regulatory quality. The human capital index does not have the expect impact. This implies that the MENA region need more developed skills to benefit from the ICT divides. Their actual workers' skills are not adapted to the demand of the new economy on one hand, and the institutions are not yet accountable to the extent that keeps pace with the greater digital adoption on the other. Another explanation for the observed trend may be that the actual framework of regulations is unable that ensure competition among businesses. With unchanging institutions, technology failed to deliver the expected benefits in the region.

As for the impacts of good governance on sustainable development, table below presents the estimated results (Table 4).

Results show that government effectiveness affects positively and significantly rule of law, political stability, and absence of violence. However, it is not found to have any significant effect on GDP per capita, under-five mortality, or the health index. The control of corruption has a significant impact on the variables rules of law, heath index, and ecosystem vitality. Regulatory quality has a significant and positive impact on the health variables (heath index and under-five mortality rate) and on the rule of law. The huge public investment in ICTs, in the absence of a good governance framework that embodies accountable institutions, enlarges the voice of the elite which in turn can result in policy capture and greater state control. This situation can hinder the business climate by raising natural monopolies and therefore creating more concentrated markets.

Now, the impact of e-government development on sustainable development is shown in the table below (Table 5).

Results reveal that the three components (OSI, TII, HCI) of EDGI do not have a positive and significant impact on the various dimensions of sustainable development (especially the economic and social ones). This result can be explained by the fact that moving forward with the digital governance framework in MENA countries still faces many difficulties despite the great achievements accomplished to date. The new challenges remain heavily dependent on the development stage of each organization and each country. Indeed, digital transformation faces complex challenges from economic issues, social and political matters, to technology innovation and its diffusion patterns. E-government reforms fail to be adequately embedded in public sector reform. As result, social and environmental divides seem to be limited. The e-government exerts an adverse effect on various aspects of sustainable development instead of to be a catalyst for progress. A conclusion that may emerge here is the inconclusive impact of e-government on sustainable development in MENA countries. Digital government efforts in the region are still perceived as technical support activities and not as a core strategic component for development corpus. 


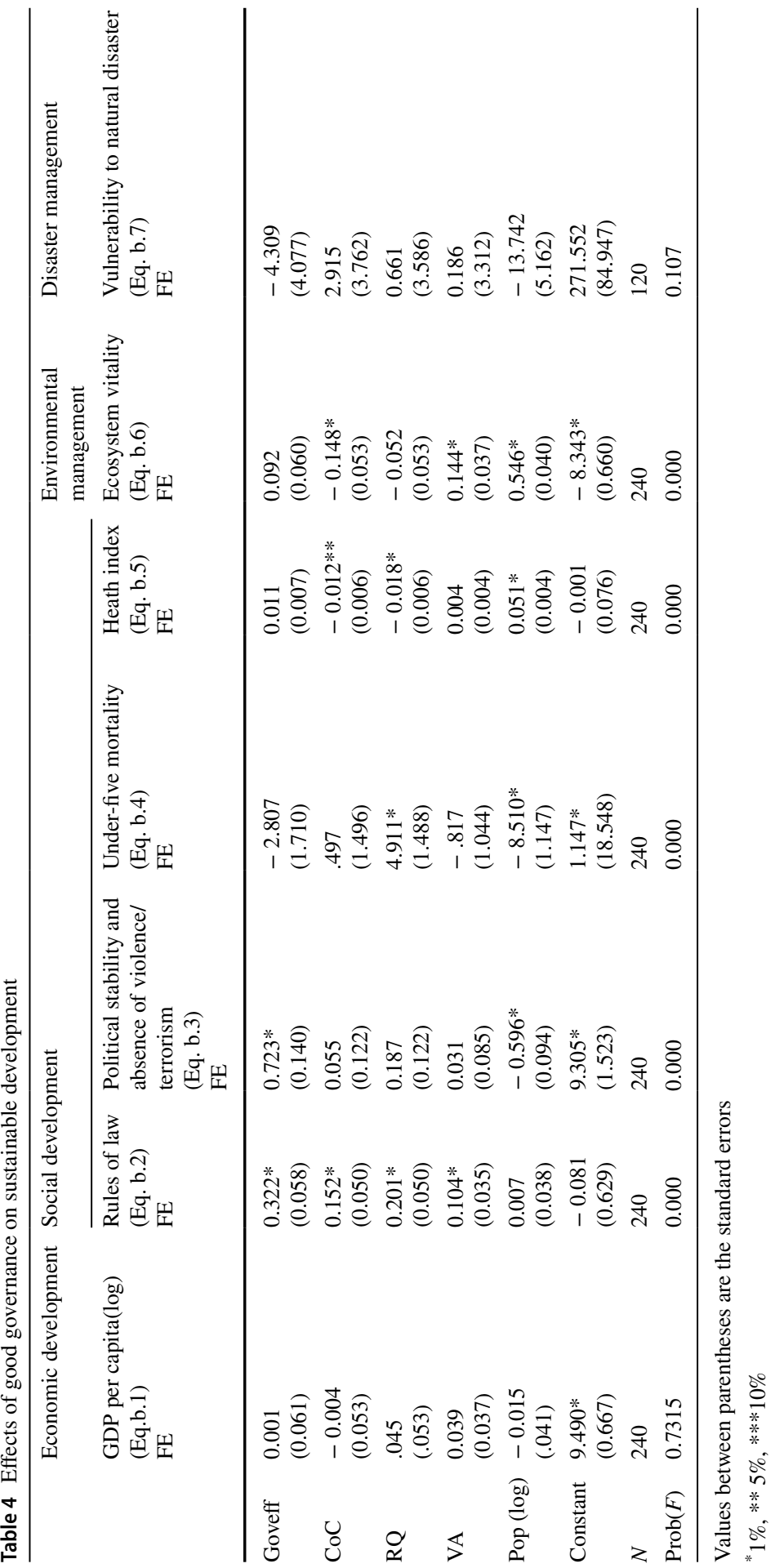




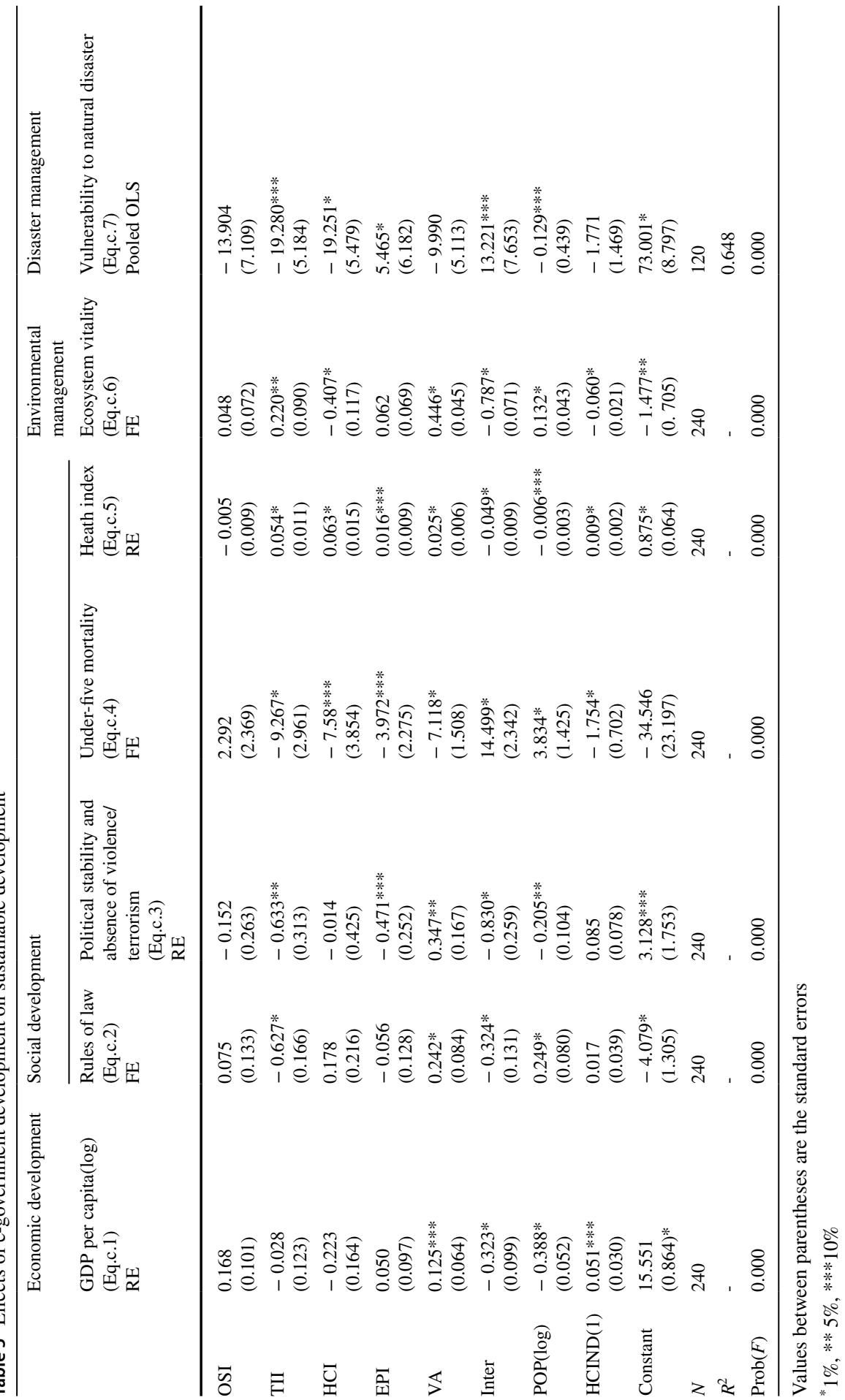


Although ICTs have spread rapidly in much of MENA countries, digital dividends - the broader development benefits from using digital technologies-have lagged behind. In many cases, e-government projects have enlarged opportunities, and get better service delivery. However, their aggregate impact has fallen short and is unevenly distributed. Along these lines, Göll and Zwiers (2018) prove the deficits in the adoption of new technologies in the MENA region vis-à-vis the major factors for success. Adequate governance for e-government projects is severely lacking in most of the MENA countries. The region stills unable to complement technology investments with appropriate economic reforms that reap digital dividends in the form of faster growth, better public services, and adequate environmental management. These challenges are preventing the digital revolution from fulfilling its transformative potential in the region.

Access to ICTs and greater digital adoption is critical, but not sufficient. Thus, digital technologies are no shortcut to sustainable development; they can be an enabler by raising the necessary reforms. The digital economy also requires what the WDR (2016) call a "strong analog component" which consists of regulations that create vibrant businesses and let firms leverage digital technologies to compete and innovate, skills that allow workers to adapt to the demands of the new economy, and institution that are accountable and that uses the internet to empower citizens. ${ }^{4}$

Thus, overcoming these challenges will require special awareness, commitment, and a particular focus on ambitious and action-oriented strategies that contribute to bypass e-government constraints, enhancing good governance, which in turn improves sustainable development and more inclusive societies.

Now, we move to comparative analysis to show the importance of e-government and good governance development strategies for sustainable development in the MENA region.

The scatter plot bow shows the relationship between the EDGI and GDP per capita.

From Fig. 2, a positive relationship between countries' EDGI performance and economic development emerges. Also, this correlation has an exponential tendency. For instance, rich Gulf countries and Turkey tend to have higher EDGI scores in relation to their gross domestic product per capita compared to other countries, in particular, Iraq, Algeria, and Egypt, which tend to have the poorest results. The other countries (Tunisia, Iran, and Lebanon) are in an intermediate position. This tendency implies that countries with more financial resources can better implement policies to develop ICTs and go forward into digitalization. However, this is not always the case; some MENA countries have high GDP per capita but receive low scores on the overall EDGI. This result suggests the role of something other than economic development alone, such as good governance performance that may also be critical in achieving e-government goals.

\footnotetext{
${ }^{4}$ It is worth noticing that the changes are not limited to economic transactions. They also include the participation of women in the labor market, ease of communication for people with disabilities, and the way people spend their leisure (WDR, 2016).
} 


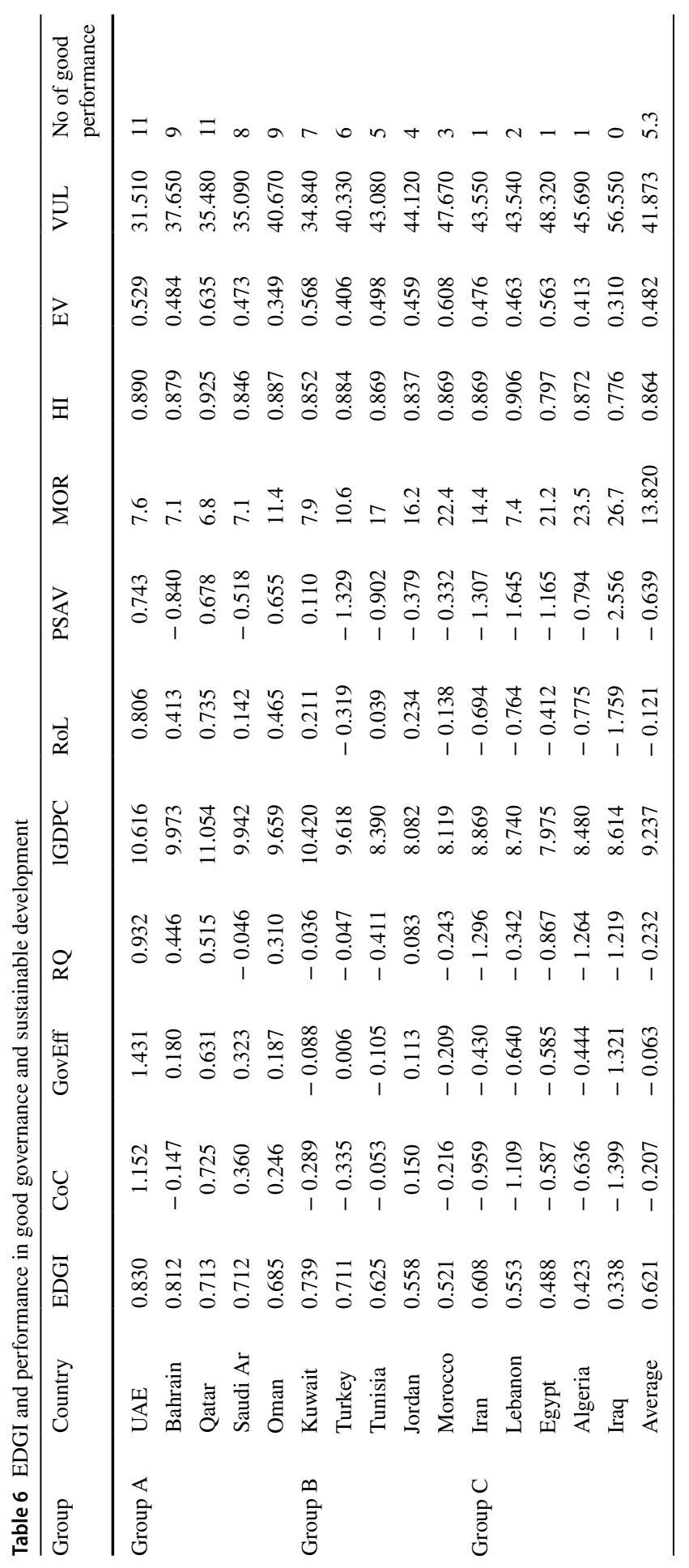




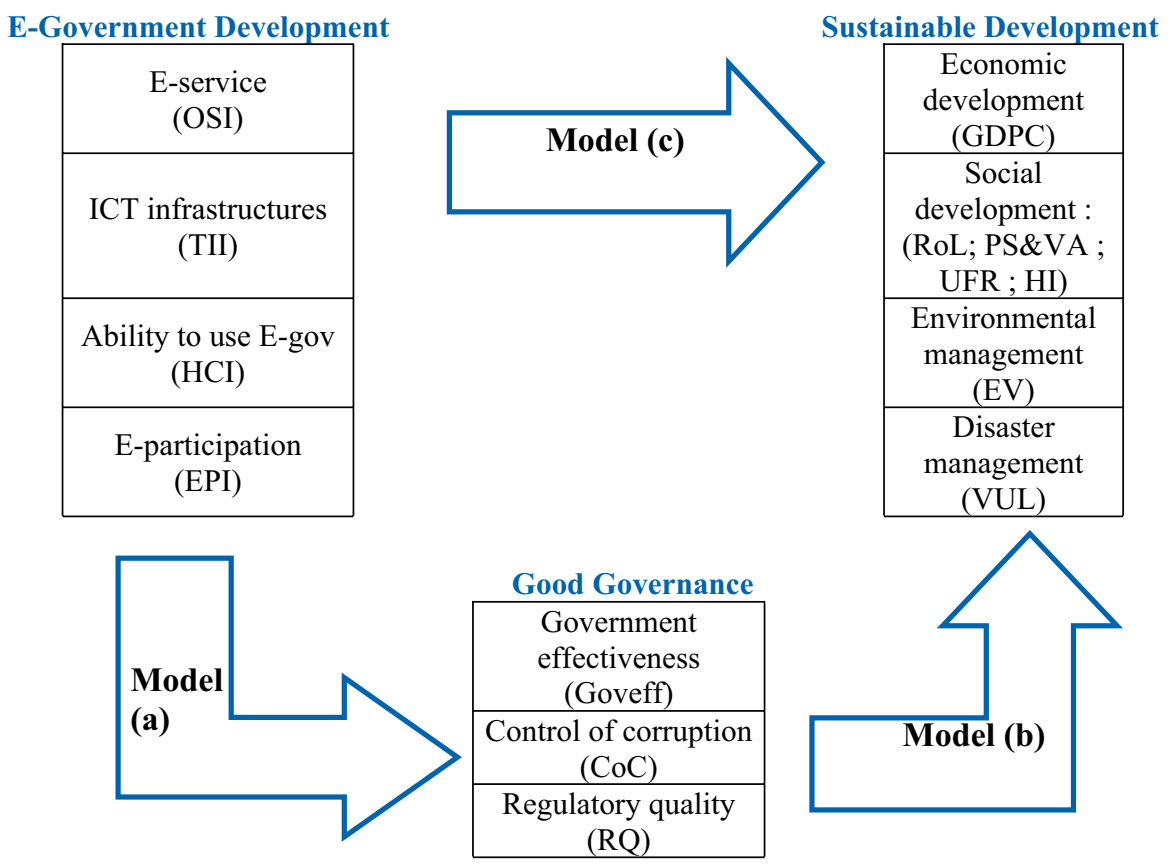

Fig. 1 Research design

Based on the results obtained from the relationships between EDGI, e-government dimensions, and various aspects of sustainable development, we divide the sample countries into groups and for each group, we put its performance in good governance

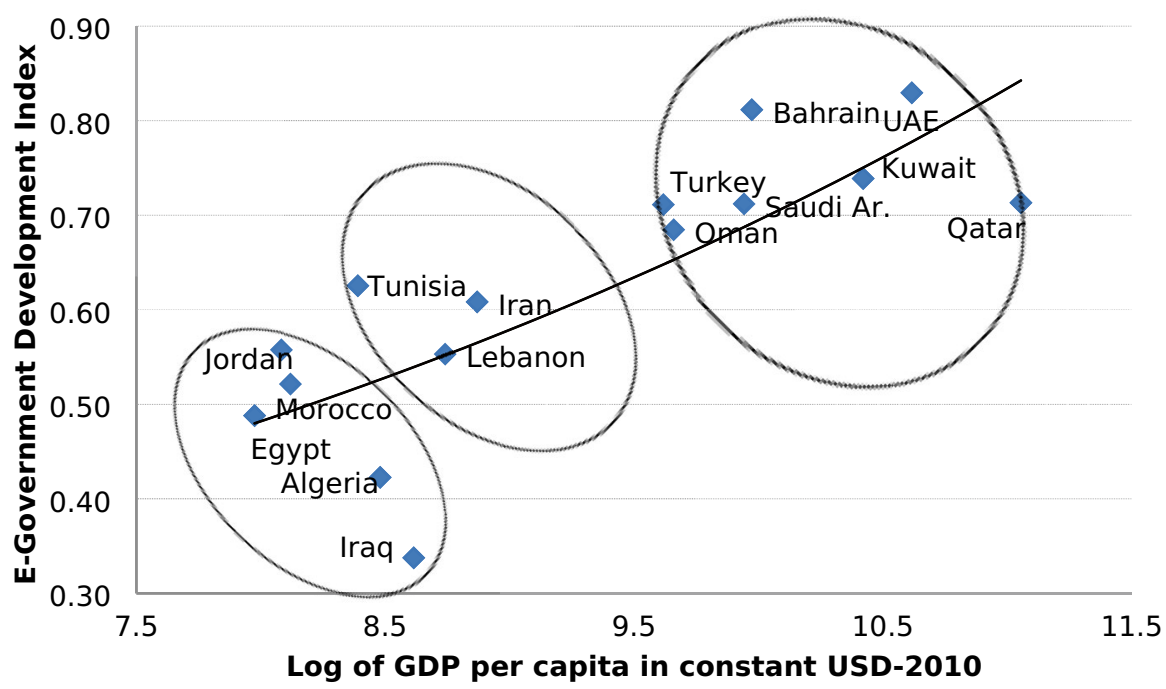

Fig. 2 Scatter plot of EDGI and GDP per capita as of 2018 


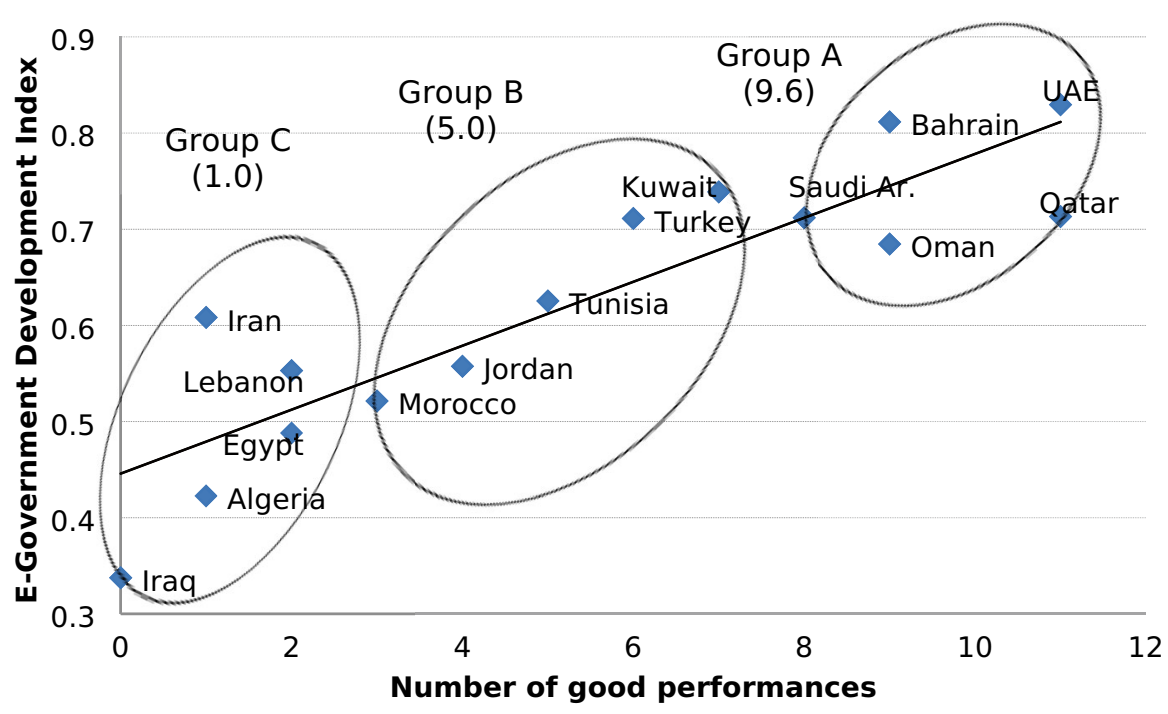

Fig. 3 Scatter plot of EDGI and the number of good performances in good governance and sustainable development as of 2018

and in sustainable development. For each country, we count the number of good performances. We will check whether the country grouping still the same (Table 6).

The results reveal that Qatar, UAE, Oman, Bahrain, and Saudi Arabia have a score ranged between 11 and 8 followed by Kuwait, Turkey, Tunisia, Jordan, and Morocco. Higher performers show higher scores across many variables.

Now, we plot a scatter of EDGI and the number of good performances in good governance and sustainable development to show the sign and tendency of the relationship and to check whether the country grouping still the same.

Figure 3 suggests that as the number of good performance increases, the e-government development index. The scatter plot shows a positive correlation between EDGI and good performances in good governance and sustainable development. The number of good performance is more dispersed in their relation with EDGI than GDP per capita in relation with EGDI, and the country grouping is not still the same. Iraq, Algeria, Egypt, Lebanon, and Iran have the lowest number of good performance and the lowest EDGI score. Gulf countries tend to have higher EDGI scores in relation to their number of good performances. The other countries are in an intermediate position. Having good performances in terms of GDP per capita and social indicators do not guarantee alone higher e-governance index (the case of Kuwait). The role of e-governance is also crucial. In this context, corruption reduces the positive contribution of good governance and thus hinders public welfare and social development. In the line with what Göll and Zwiers (2018) have argued, bureaucracy, combined with lack of government support in many MENA countries, has led to a situation that seems less open to startups than in many regions in the world.

Therefore, the conclusion is that e-government can contribute heavily to sustainable development but first it should have the expected positive impacts on good governance. 


\section{Conclusion and Policy Recommendations}

Electronic government and good governance have been a topic of discussion in the international arena. Indeed, these two frameworks are pivotal to the sustainable development process. ICTs and digital technologies are one of the most transformational factors of our time, including their impact on effective good governance and sustainable development.

The paper has investigated how digital technologies can enhance good governance in MENA countries. Also, it has examined how improvements in electronic government and good governance can contribute to sustainable development; and whether these countries take advantage of the rapid technological change to make the region more prosperous and inclusive. The main results reveal that e-government development works well for the control of corruption and government effectiveness, and to a lesser extent, for regulatory quality. The human capital index does not have the expected impact. This implies that the MENA region needs more developed skills to benefit from the ICT divides. Most indicators of good governance showed a positive contribution to sustainable development. The three components of EDGI (OSI, TII, $\mathrm{HCI}$ ) do not have a positive and significant impact on the various dimensions of sustainable development. Our conclusion is that digital government efforts in the region are still perceived as technical support activities and not as a core strategic component for development corpus.

In order to seek the economic, social, and environmental needs sustainability for MENA countries, it is crucial to establish good governance by forming an institutional environment capable to enable government with more effective and efficient tools for more successful development plans. However, the region suffers from a lack of adequate training and knowledge about the technology, access to it, and knowledge of how to best apply it. The gather benefits, policies on the use of digital technologies need to be adequately embedded in public sector reform. MENA countries should promote competitive business environments, enhance accountability, and upgrade education and skills development systems to prepare people for the jobs of the future. The race is between skills and technology, while the outcome will settle on whether the dividends from ICTs are realized and the benefits widely shared.

Bring digital technology and governance practices together at the forefront of sustainable development strategies and provide new and innovative technological options leading to improve governance strategies may contribute heavily to achieve sustainable development in all dimensions. A particular emphasis on building a digitally inclusive society is needed. The actual increase in access to digital technologies should bring more choice and greater convenience in the region. This can be done through inclusion, efficiency, and innovation which are capable to provide opportunities that were previously out of reach to the poor and disadvantaged. In the line with what the World Development Report concludes, the full benefits of the ICTs' revolution will not be realized unless MENA countries continue to improve their business climate, invest in education and health, and promote good governance through strong institutions. Sound strategic and policy framework that progressively revises the contribution of ICTs may support the shift towards good governance 
and thus more sustained development. The challenge is to start adequate reforms to maximize digital dividends and to prepare for any disruptions. The digital economy is changing rapidly. So, non-undertaking the necessary reform in terms of digital complements such as regulation, skills, and institutions will raise the opportunity cost. Any failure to reform will lead to a situation of falling farther behind those who do reform. Strengthening the interaction between technology and its complements is more urgent than ever before.

\section{Appendix 1. Variables of the study}

\begin{tabular}{|c|c|c|c|}
\hline Area & Factors & $\begin{array}{l}\text { Variables/conceptual } \\
\text { definition }\end{array}$ & Sources \\
\hline ICT infrastructure & $\begin{array}{l}\text { Telecommunication } \\
\text { infrastructure index } \\
\text { (TII) }\end{array}$ & $\begin{array}{l}\text { Internet users (\%) } \\
\text { Main fixed phone lines } \\
(\%) \\
\text { Mobile subscribers (\%) } \\
\text { Fixed Internet subscrip- } \\
\text { tions (\%) } \\
\text { Fixed broadband sub- } \\
\text { scriptions (\%) } \\
\text { Wireless broadband } \\
\text { subscriptions (\%) }\end{array}$ & $\begin{array}{l}\text { UN e-government survey } \\
\text { 2003-2018 (based on } \\
\text { ITU's IDI) }\end{array}$ \\
\hline $\begin{array}{l}\text { Ability to use e-gov- } \\
\text { ernment }\end{array}$ & $\begin{array}{l}\text { Human capital index } \\
\text { (HCI) }\end{array}$ & $\begin{array}{l}\text { Adult literacy }(\%) \\
\text { Primary, secondary, } \\
\text { tertiary gross enroll- } \\
\text { ment }(\%) \\
\text { Expected years of } \\
\text { education } \\
\text { Mean years of school- } \\
\text { ing }\end{array}$ & $\begin{array}{l}\text { UN e-government survey } \\
\text { 2003-2018 (based on } \\
\text { UNDP's HDR) }\end{array}$ \\
\hline E-public service & $\begin{array}{l}\text { Online service index } \\
\text { (OSI) }\end{array}$ & $\begin{array}{l}\text { National website's } \\
\text { services level (e.g., } \\
\text { government portal, } \\
\text { ministries' websites) }\end{array}$ & $\begin{array}{l}\text { UN e-government survey } \\
\text { 2003-2018 }\end{array}$ \\
\hline E-democracy & $\begin{array}{l}\text { E-participation index } \\
\text { (EPI) }\end{array}$ & $\begin{array}{l}\text { E-information, e-con- } \\
\text { sultation, e-decision } \\
\text { making }\end{array}$ & \\
\hline
\end{tabular}




\begin{tabular}{|c|c|c|c|}
\hline Area & Factors & $\begin{array}{l}\text { Variables/conceptual } \\
\text { definition }\end{array}$ & Sources \\
\hline $\begin{array}{l}\text { Government transpar- } \\
\text { ency }\end{array}$ & $\begin{array}{l}\text { Control of corruption } \\
\text { (CoC) }\end{array}$ & $\begin{array}{l}\text { The extent to which } \\
\text { public power is exer- } \\
\text { cised for private gain, } \\
\text { including both petty } \\
\text { and grand forms of } \\
\text { corruption } \\
\text { Capture of the state } \\
\text { by elites and private } \\
\text { interests }\end{array}$ & \multirow[t]{6}{*}{$\begin{array}{l}\text { World Bank's Worldwide } \\
\text { governance indicators } \\
\text { (WGIs) 2003-2018 } \\
\text { combined from several } \\
\text { sources including EIU, } \\
\text { IMD, ADB, freedom } \\
\text { house, and so on }\end{array}$} \\
\hline \multirow[t]{5}{*}{ Government capabilities } & \multirow[t]{4}{*}{$\begin{array}{l}\text { Government effective- } \\
\text { ness (Goveff) }\end{array}$} & $\begin{array}{l}\text { Quality of public } \\
\text { services }\end{array}$ & \\
\hline & & $\begin{array}{l}\text { Quality of civil service } \\
\text { and the degree of its } \\
\text { independence from } \\
\text { political pressures }\end{array}$ & \\
\hline & & $\begin{array}{l}\text { Quality of policy } \\
\text { formulation and } \\
\text { implementation }\end{array}$ & \\
\hline & & $\begin{array}{l}\text { Credibility of the gov- } \\
\text { ernment's commit- } \\
\text { ment to policies }\end{array}$ & \\
\hline & Regulatory quality (RQ) & $\begin{array}{l}\text { The ability of the } \\
\text { government to } \\
\text { formulate and imple- } \\
\text { ment sound policies } \\
\text { and regulations that } \\
\text { promote private sector } \\
\text { development }\end{array}$ & \\
\hline Economic development & GDP per capita (GDPC) & $\begin{array}{l}\text { GDP (constant } 2010, \\
\text { USD)/population }\end{array}$ & World Bank 2003-2018 \\
\hline
\end{tabular}




\begin{tabular}{|c|c|c|c|}
\hline Area & Factors & $\begin{array}{l}\text { Variables/conceptual } \\
\text { definition }\end{array}$ & Sources \\
\hline \multirow[t]{4}{*}{ Social development } & Rule of law (RoL) & $\begin{array}{l}\text { The extent to which } \\
\text { agents have confi- } \\
\text { dence in and abide by } \\
\text { the rules of society } \\
\text { Quality of contract } \\
\text { enforcement, property } \\
\text { rights, the police, and } \\
\text { the courts } \\
\text { Likelihood of crime and } \\
\text { violence }\end{array}$ & \multirow[t]{2}{*}{$\begin{array}{l}\text { World Bank's Worldwide } \\
\text { governance indicators } \\
\text { (WGIs) 2002-2018 }\end{array}$} \\
\hline & $\begin{array}{l}\text { Political stability and } \\
\text { absence of violence/ } \\
\text { terrorism (PS\&AVT) }\end{array}$ & $\begin{array}{l}\text { Unlikelihood that the } \\
\text { government will } \\
\text { be destabilized or } \\
\text { overthrown by uncon- } \\
\text { stitutional or violent } \\
\text { means, including } \\
\text { politically motivated } \\
\text { violence and terror- } \\
\text { ism }\end{array}$ & \\
\hline & $\begin{array}{l}\text { Under-five mortality } \\
\text { rate (UFM) }\end{array}$ & $\begin{array}{l}\text { Under-five mortality } \\
\text { (per } 1000 \text { live births) }\end{array}$ & $\begin{array}{l}\text { UNDP's human develop- } \\
\text { ment index (HDI) }\end{array}$ \\
\hline & Health index (HI) & Life expectancy at birth & \\
\hline \multirow[t]{12}{*}{ Ecosystem vitality $(\mathrm{EV})$} & Water resources & $\begin{array}{l}\text { Wastewater treatment } \\
\text { level }\end{array}$ & \multirow{12}{*}{$\begin{array}{l}\text { Environmental perfor- } \\
\text { mance index (EPI) of } \\
\text { Yale Univ. (YCELP) } \\
\text { and Columbia Univ. } \\
\text { (CIESIN) 2002-2016 } \\
\text { combined from several } \\
\text { sources Including } \\
\text { WHO, UNICEF, World } \\
\text { Bank, UNEP, IEA, } \\
\text { FAO, and so on }\end{array}$} \\
\hline & Agriculture & $\begin{array}{l}\text { Agricultural subsidies } \\
\text { Pesticide regulation }\end{array}$ & \\
\hline & Forests & Change in forest cover & \\
\hline & Fisheries & $\begin{array}{l}\text { Coastal shelf fishing } \\
\text { pressure }\end{array}$ & \\
\hline & & Fish stocks & \\
\hline & \multirow[t]{4}{*}{ Biodiversity and habitat } & $\begin{array}{l}\text { Terrestrial protected } \\
\text { areas (national biome } \\
\text { weights) }\end{array}$ & \\
\hline & & $\begin{array}{l}\text { Terrestrial protected } \\
\text { areas (global biome } \\
\text { weights) }\end{array}$ & \\
\hline & & Marine protected areas & \\
\hline & & $\begin{array}{l}\text { Critical habitat protec- } \\
\text { tion }(\%)\end{array}$ & \\
\hline & \multirow[t]{3}{*}{ Climate and energy } & $\begin{array}{l}\text { Trend in carbon } \\
\text { intensity }\end{array}$ & \\
\hline & & $\begin{array}{l}\text { Change of trend in } \\
\text { carbon intensity }\end{array}$ & \\
\hline & & $\begin{array}{l}\text { Trend in } \mathrm{CO}_{2} \text { emissions } \\
\text { per } \mathrm{kWh}\end{array}$ & \\
\hline
\end{tabular}




\begin{tabular}{|c|c|c|c|}
\hline Area & Factors & $\begin{array}{l}\text { Variables/conceptual } \\
\text { definition }\end{array}$ & Sources \\
\hline \multirow[t]{11}{*}{$\begin{array}{l}\text { Vulnerability to natural } \\
\text { disaster (VUL) }\end{array}$} & Susceptibility & $\begin{array}{l}\text { Population without } \\
\text { access to drinking } \\
\text { water(a) and sanita- } \\
\text { tion }(\%)\end{array}$ & $\begin{array}{l}\text { World Risk Report } \\
\text { (Alliance Development } \\
\text { Works and UNU-EHS) } \\
\text { 2011-2018 }\end{array}$ \\
\hline & & Nutrition & \\
\hline & & $\begin{array}{l}\text { Poverty and dependen- } \\
\text { cies }\end{array}$ & \\
\hline & & $\begin{array}{l}\text { Economic capacity and } \\
\text { income distribution }\end{array}$ & \\
\hline & Coping capacities & $\begin{array}{l}\text { Government and } \\
\text { authorities }\end{array}$ & \\
\hline & & Medical services & \\
\hline & & Material coverage & \\
\hline & Adaptive capacities & Education and research & \\
\hline & & Gender equity & \\
\hline & & $\begin{array}{l}\text { Environmental status } \\
\text { and ecosystem protec- } \\
\text { tion }\end{array}$ & \\
\hline & & Investment & \\
\hline
\end{tabular}

\section{Appendix 2. Evolution of Indicators (Average) between 2003 and 2018}

\section{E-government Development}

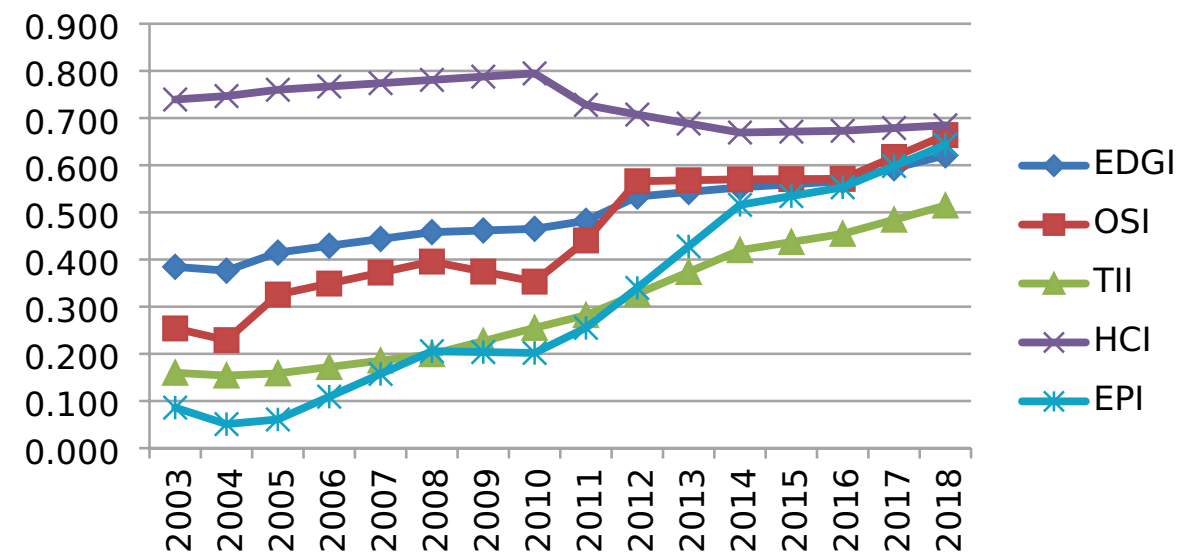




\section{Good Governance}

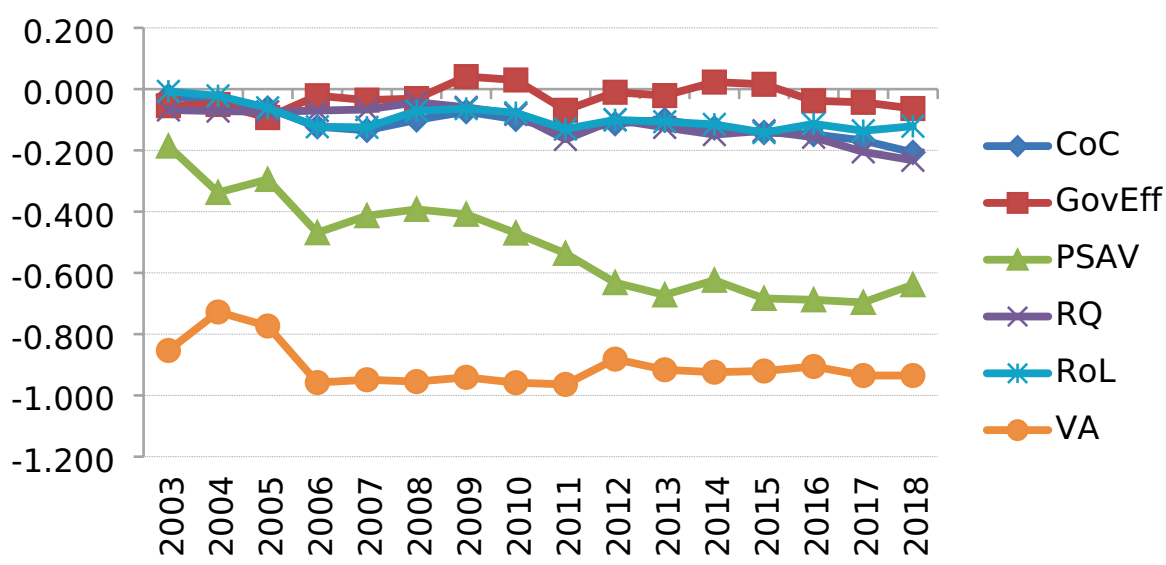

\section{Sustainable Development}

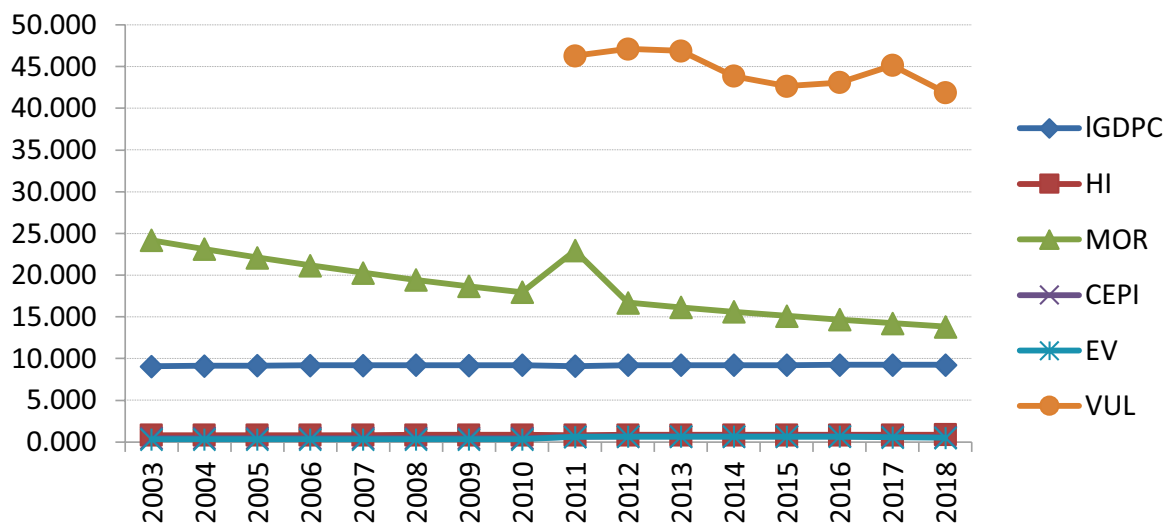

\section{Appendix 3. Model Selection Based on Hausman Test, F Test, and LM} Test

\begin{tabular}{|c|c|c|c|c|c|c|c|}
\hline & \multicolumn{2}{|l|}{ F test } & \multicolumn{2}{|l|}{ LM test } & \multicolumn{2}{|c|}{ Hausman test } & \multirow[t]{2}{*}{ Selected model } \\
\hline & F statistic & Prob $>F$ & Chi(2) & Prob $>$ chi 2 & Chi(2) & Prob $>$ Chi2 & \\
\hline Model a.1 & 0.91 & $0.5539^{\mathrm{a}}$ & 793.70 & $0.000^{\mathrm{r}}$ & - & - & Pooled OLS \\
\hline Model a.2 & 1.65 & $0.0681^{\mathrm{a}}$ & 620.89 & $0.000^{r}$ & - & - & Pooled OLS \\
\hline Model a.2 & 1.55 & $0.0947^{\mathrm{a}}$ & 547.63 & $0.000^{\mathrm{r}}$ & - & - & Pooled OLS \\
\hline
\end{tabular}




\begin{tabular}{|c|c|c|c|c|c|c|c|}
\hline & \multicolumn{2}{|l|}{$\mathrm{F}$ test } & \multicolumn{2}{|l|}{ LM test } & \multicolumn{2}{|c|}{ Hausman test } & \multirow[t]{2}{*}{ Selected model } \\
\hline & F statistic & Prob $>F$ & Chi(2) & Prob $>$ chi 2 & Chi(2) & Prob $>$ Chi 2 & \\
\hline Model b.1 & 18.19 & $0.000^{r}$ & 1474.86 & $0.000^{r}$ & 16.50 & $0.0056^{\mathrm{r}}$ & FF model \\
\hline Model b.2 & 2.00 & $0.0167^{\mathrm{r}}$ & 781.46 & $0.000^{\mathrm{r}}$ & 13.18 & $0.0218^{r}$ & FF model \\
\hline Model b.3 & 2.69 & $0.0009^{r}$ & 467.66 & $0.000^{r}$ & 36.47 & $0.000^{r}$ & FF model \\
\hline Model b.4 & 71.14 & $0.000^{\mathrm{r}}$ & 489.76 & $0.000^{\mathrm{r}}$ & 111.48 & $0.000^{\mathrm{r}}$ & FF model \\
\hline Model b.5 & 48.56 & $0.000^{r}$ & 409.62 & $0.000^{r}$ & 254.90 & $0.000^{\mathrm{r}}$ & FF model \\
\hline Model b.6 & 48.56 & $0.000^{r}$ & 409.62 & $0.000^{r}$ & 172.38 & $0.000^{r}$ & FF model \\
\hline Model b.7 & 3.11 & $0.0054^{\mathrm{r}}$ & 46.07 & $0.000^{\mathrm{r}}$ & 14.52 & $0.0126^{\mathrm{r}}$ & FF model \\
\hline Model c. 1 & 13.66 & $0.000^{\mathrm{r}}$ & 792.34 & $0.000^{\mathrm{r}}$ & 1.36 & $0.9948^{\mathrm{a}}$ & RE model \\
\hline Model c. 2 & 3.57 & $0.000^{r}$ & 763.10 & $0.000^{r}$ & 30.69 & $0.0002^{\mathrm{r}}$ & FF model \\
\hline Model c. 3 & 4.93 & $0.000^{r}$ & 832.41 & $0.000^{r}$ & 7.73 & $0.4601^{\mathrm{a}}$ & RE model \\
\hline Model c. 4 & 42.72 & $0.000^{r}$ & 486.79 & $0.000^{r}$ & 19.07 & $0.0145^{\mathrm{r}}$ & FF model \\
\hline Model c.5 & 29.71 & $0.000^{r}$ & 1067.96 & $0.000^{r}$ & 1.99 & $0.9813^{\mathrm{a}}$ & RE model \\
\hline Model c.6 & 21.91 & $0.000^{r}$ & 57.82 & $0.000^{r}$ & 22.35 & $0.0043^{r}$ & FF model \\
\hline Model c.7 & 1.98 & $0.0773^{\mathrm{a}}$ & 19.47 & $0.000^{r}$ & - & - & Pooled OLS \\
\hline
\end{tabular}

For the $\mathrm{F}$ test, the null hypothesis is that the coefficients for all years are jointly equal to zero. For LM test, the null hypothesis in the LM test is that variance across entities is zero, i.e., no significant difference across units (i.e., no panel effect). For Hausman test, the null hypothesis denotes non-correlation between an individual effect and regressor. We conduct the Hausman test when both hypotheses of the F test and LM test are all rejected

(a): The null hypothesis is accepted. (R): The null hypothesis is rejected

Funding This work was sponsored by the Economic Research Forum (ERF) and has benefited from financial and intellectual support.

\section{Declarations}

Conflict of Interest The author declares no competing interests.

\section{References}

Andersen, T. B., \& Rand, J. (2005). Mice do not take bribes. Institute of Economics, University of Copenhagen.

Balagti, B. (2001). Economic Analysis of Panel Data, 2nd ed., John Wiley and Sons, Chichester.

Baller, S. Dutta, S. \& Lanvin, B. (2016). The Global Information Technology Report 2016. Innovating in the Digital Economy, Geneva, World Economic Forum, http://reports.weforum.org/global-informationtechnology-report-2016

Benjamin, P. (2001). Community development and democratization through information technology: building the new South Africa. In R. Heeks (Ed.), Reinventing Government in the Information Age: International Practice in IT-enabled Public Sector Reform (pp.194-210). London: Routledge.

Chambers, J. (2015). How Technology Is Transforming the Middle East, in World Economic Forum Articles, 20 May, https://www.weforum.org/agenda/2015/05/how-technology-istransforming-the-middle-east 
Craig, D., \& Porter, D. (2006). Development beyond neo-liberalism? Governance, poverty reduction and political economy. Cambridge University Press.

Dhaoui, I. (2019a). Good governance for sustainable development. MPRA Paper No. 92544.

Dhaoui, I. (2019b). Electronic governance: An overview of opportunities and challenges. MPRA Paper No. 92545.

Dhaoui, I. (2019c). Achieving sustainable development goals in MENA countries: an analytical and econometric approach. Hal archives, hal-02075484.

Dhaoui, I. (2020). Youth unemployment and social inclusion in MENA countries: Challenges and patterns. Deutsches Orient Institute Orient magazine, 61(1), 7-16.

Dodd, J. (2000). Delivering on the E-government promise. A government technology industry profile: NIC. from http://bilisimsurasi.org.tr/cg/egitim/kutuphane/NIC.qxd.pdf

ESCWA (Economic and Social Commission for Western Asia). (2015). Role of Technology in Sustainable Development in the Arab Region. Expert report for the Arab Sustainable Development Report, New York, United Nations, 17 April, http://web.archive.org/web/20171013135546/

Estevez, E., \& Janowski, T. (2013). Electronic governance for sustainable development : conceptual framework and state of research. Government Information Quarterly, 30, S94-S109.

Estevez E., Janowski T., Dzhusupova Z. (2013). Electronic Governance for Sustainable Development - How EGOV Solutions Contribute to SD Goals? The Proceedings of the 14th Annual International Conference on Digital Government Research.

Gartner Group (2002). GartnerEXP says a majority of e-government initiatives fail or fall short of expectations. GartnerEXP.

Gelvanovska, N., Rogy M., Rossotto C. M. (2014). Broadband Networks in the Middle East and North Africa : Accelerating High-Speed Internet Access. Directions in Development--Communication and Information Technologies;. Washington, DC: World Bank.

Glass, L. M., \& Newig, J. (2019). Governance for achieving the sustainable development goals: How important are participation, policy coherence, reflexivity, adaptation and democratic institutions? Earth Syst. Governance, 2, Art. no. 100031

Göll, E., \& Zwiers, J. (2018). Technological trends in the MENA region: the cases of digitalization and Information and Communications Technology (ICT). MENARA Working Papers No. 23.

Gordon, F.T. (2002). E-government-introduction. ERCIM News 48.

Hauner, D. \& Kyobe, A. (2010). Determinants of government efficiency. World Development, 38, pp.15271542. https://doi.org/10.17705/1CAIS.01539

Heeks, R. (2003). Most eGovernment for Development Projects Fail: How can risks be reduced, iGovernment Information, Systems, Technology, and the Public Sector, Working Paper No. 14, Institute of Development Policy and Management, University of Manchester.

Heeks, R. (2006). Implementing and managing e-government: an international text. Sage Publications.

Hout, W. (2007). The Politics of Aid Selectivity: Good governance criteria in World Bank, US and Dutch development assistance. London \& New York: Routledge.

Hsiao, C. (2003). Analysis of Panel Data Second Edi., Cambridge University Press New York, USA.

Juknevciene, V., \& Krateivaite, R. (2012). Good governance as the instrument for the implementation of sustainable development's conception. Social Research $\mathrm{Nr}, 3(28), 28-42$.

Kanungo, S. (2003). Information village: bridging the digital divide in rural India. In S. Krishna \& S. Madon (Eds.), The Digital Challenge: Information Technology in the Development Context. (pp. 103-124). Ashgate.

Kennedy, P. (2008). A guide to econometrics, 6th ed. Malden, MA: Blackwell Publishing Baltagi, Badi H. 2001. Econometric Analysis of Panel Data. Wiley, John \& Sons.

Kettani, D., Moulin B. (2014). E-government for good governance in developing countries: empirical evidence from the eFez Project. International Development Research Centre.

Kioe, S. Y. (2010). Good urban governance in Southeast Asia. Environment and Urbanization Asia, 1(2), 131-147.

Lim, J.H. (2014). E-gov for Sustainable Development in SIDS United Nations Project Office on Governance (UNPOG) DPADM/UNDESA.

Madon, S. (2009). E-Governance for Development. In: e-Governance for Development. Technology, Work and Globalization. Palgrave Macmillan, London.

Mahmood, R. (2004). Can information and communication technology help reduce corruption? How so and why not: two case studies from south Asia. Perspectives on Global Development and Technology, 3(3), 347-373.

Marthandan, G., \& Tang, C. M. (2010). Information technology evaluation: issues and challenges. Journal of Systems and Information Technology, 12(1), 37-55.

Mira, R. \& Hammadache, A. (2017). Relationship between good governance and economic growth: a contribution to the institutional debate about state failure in developing countries. hal 01593290. 
O’Sullivan, A, marie-estelle, R. \& Galvez Mendez, J. (2012). "Opportunities and challenges in the MENA Region,” OECD Publishing. http://www.oecd.org/mena/49036903.pdf

OECD. (2017). Benchmarking Digital Government Strategies in MENA Countries. OECD Digital Government Studies, OECD Publishing. https://doi.org/10.1787/9789264268012-en

Ojha, A., Palvia, S., Gupta, M. P. (2008). A model for impact of e-government on corruption: exploring theoretical foundations.

Park, H. M. (2011). Practical guides to pane data modeling: a step by step analysis using Stata. International University of Japan.

Pathak, R. D., Singh, G., Belwal, R., \& Smith, R. F. I. (2007). E-governance and corruption developments and issues in Ethiopia. Public Organization Review, 7(3), 195-208.

Shylendra, H. S., \& Bhirdikar, K. (2005). Good governance and poverty alleviation programmes: a critical analysis of the Swarnjayanti Gram SwarozgarYojana. International Journal of Rural Management, 1(2), 203-221.

Signore, O., Chesi, F., Palloti, M. (2005). E-government: challenges and opportunities. CMG itay-XIX Annual Conference.

Spremić, M., imurina, aković, B., \& Ivanov, M. (2009). Government in transition economies. World Academy of Science, Engineering and Technology, 53. University of Zagreb, Croatia.

Thunert, M. (2009). The Information and Decision Support Centre (IDSC) of the Egyptian Cabinet: a think tank in the making", in Zeitschrift für Politikberatung, 2, No. 4 , p. 679-684.

UN. (2020) The Impact of COVID-19 on the Arab Region: An Opportunity to Build Back Better. Policy brief.

UNDESA. (2003). E-government as a free lunch? Development Administration, 106, 6-8.

UNDP. (2012). Arab Knowledge Report 2010/2011. Preparing Future Generations for the Knowledge Society. https://www.knowledge4all.com/en/10/Pages/Arab-Knowledge-Report-2010/-2011--Preparing-FutureGenerations-for-the-Knowledge-Society

UNDP. (2016). Arab Human Development Report 2016. Youth and the Prospects for Human Development in a Changing Reality. http://arab-hdr.org/Reports/2016/2016.aspx

UNDP. (2014). Governance for sustainable development integrating governance in the post-2015 development framework. Report.

UNESCO. 2005. E-government toolkit for developing countries. Report.

UNU-IAS. (2015). Integrating the governance into the sustainable development goals. UNU-IAS Policy Brief $\mathrm{n}^{\circ} 3$.

UNWCED. (1987). Our common future: World Commission on Environment and Development. Oxford University Press.

WDR. (2016). Digital Dividends. World Bank.

WEF. (2017). The Future of Jobs and Skills in the Middle East and North Africa. Preparing the Region for the Fourth Industrial Revolution, May. https://www.weforum.org/reports/the-future-of-jobs-and-skillsin-the-middle-east-and-north-africa-preparing-theregion-for-the-fourth-industrial-revolution

West, D., Noveck, B. S., \& Siirianni, C. (2009). Innovation in government: how to make the public sector faster, smarter and more connected. The Booking Institute.

Wooldridge, J. M. (2013). Introductory econometrics: a modern approach. South-Western, Cengage Learning, 5th Edition.

World Bank. (2014). Regional Economic Outlook for Middle East and North Africa”. The World Bank.

Publisher's Note Springer Nature remains neutral with regard to jurisdictional claims in published maps and institutional affiliations.

\section{Authors and Affiliations}

\section{lyad Dhaoui ${ }^{1}$ (D)}

1 Tunisian Institute of Competitiveness and Quantitative Studies, 27, Liban Street, Belvedere, 1002 Tunis, Tunisia 